\title{
Fos expression in the prefrontal cortex and mesencephalic dorsal raphe nucleus in lactating rats after social instigation
}

\author{
Caroline Perinazzo da Veiga ${ }^{1}$, Elisa Winkelmann-Duarte ${ }^{2}$, Eloisa Pavesi ${ }^{2}$, Simone Mattos \\ Louzada $^{1}$, Klaus A. Miczek ${ }^{3}$, Aldo Bolten Lucion ${ }^{1}$, and Rosa Maria Martins de Almeida ${ }^{1}$ \\ 1- Universidade Federal do Rio Grande do Sul, Porto Alegre, RS, Brazil \\ 2- Universidade Federal de Santa Catarina, Florianópolis, SC, Brazil \\ 3- Tufts University, Boston, MA, USA
}

\begin{abstract}
Females are often less aggressive than males, but they exhibit high levels of agonistic behavior against an intruder in the area of the nest during lactation. This behavior is referred to as maternal aggression. In rats, maternal aggressive behavior occurs more often from postpartum day 3 (PPD 3) to PPD 12. Social instigation is an experimental protocol used to increase the levels of aggression that are typical of the species. In the present study we used social instigation to analyze the expression of a marker of neuronal activity, c-fos. Lactating rats on PPD 5, in the presence of their pups, were divided into four groups: (1) no social instigation and no aggressive behavior, (2) social instigation and no aggressive behavior, (3) no social instigation and aggressive behavior, and (4) social instigation and aggressive behavior. Sixty minutes after the aggression test we used immunohistochemistry to detect Fos in two brain regions, the ventral-orbital region of the prefrontal cortex (VO PFC) and dorsal raphe nucleus (DRN). Our results showed that rats with aggressive behavior that were provoked exhibited an increase in Fos expression in the VO PFC compared with the control group (i.e., no social instigation and no aggressive behavior). No change in Fos expression was found in the DRN. These results complement previous findings with microinjection of serotonin 5-hydroxytryptamine-1B receptor agonists into the same region, demonstrating that the VO PFC is an important region in the modulation of maternal aggressive behavior. Keywords: social instigation, maternal aggression, Fos, prefrontal cortex, dorsal raphe nucleus.
\end{abstract}

Received 11 September 2012; received in revised form 5 January 2013; accepted 18 February 2013. Available online 27 June 2013.

\section{Introduction}

The behavioral repertoire of females during maternity changes drastically compared with other periods of the reproductive cycle (Ferreira, Pereira, Agrati, Uriarte, \& Fernández-Guasti, 2002). Motherhood involves changes in the perception of mothers toward offspring (Kinsley \& Bridges, 1990; Rosenblatt, 1975), providing a link between mothers and offspring and causing significant changes in the response of mothers to environmental stimuli (Agrati, Zuluaga,

Caroline Perinazzo da Veiga, Programa de Pós-Graduação em Neurociências, Instituto de Ciências Básicas da Saúde, Universidade Federal do Rio Grande do Sul, Porto Alegre, RS, Brazil. Elisa Winkelmann-Duarte, Departamento de Ciências Morfológicas, Centro de Ciências Biológicas, Universidade Federal de Santa Catarina, Florianópolis, SC, Brazil. Eloisa Pavesi, Departamento de Farmacologia, Universidade Federal de Santa Catarina, Campus Universitário - Trindade, Florianópolis, SC, Brazil. Simone Mattos Louzada, Laboratório de Neuroendocrinologia do Comportamento, Instituto de Ciências Básicas da Saúde, Universidade Federal do Rio Grande do Sul, Porto Alegre, RS, Brazil. Klaus A. Miczek, Departments of Psychology, Pharmacology, Neuroscience, and Psychiatry, Tufts University, Medford and Boston, MA, USA. Aldo Bolten Lucion,
Fernández-Guasti, Meikle, \& Ferreira, 2008). Females are often less aggressive than males, but they exhibit high levels of agonistic behavior against an intruder in the area of the nest during lactation (Bridges, 1996; Erskine, Barfield, \& Goldman, 1980; Giovenardi, Consiglio, Barros, \& Lucion, 2000; Olivier \& Young, 2002; Lonstein \& Gammie, 2002). In rats, maternal aggressive behavior occurs more frequently from postpartum day 3 (PPD 3) to PPD 12. During this period, females direct intense care toward their pups

Departamento de Fisiologia, Programa de Pós-Graduação em Neurociências, Instituto de Ciências Básicas da Saúde, Universidade Federal do Rio Grande do Sul, Porto Alegre, RS, Brazil. Rosa Maria Martins de Almeida, Instituto de Psicologia do Desenvolvimento e da Personalidade, Universidade Federal do Rio Grande do Sul, Porto Alegre, RS, Brazil, and Laboratório de Psicologia Experimental, Neurociências e Comportamento, Pesquisadora do CNPq. Correspondence regarding this article should be directed to: Rosa Maria Martins de Almeida, Instituto de Psicologia, Universidade Federal do Rio Grande do Sul, Rua Ramiro Barcelos, 2600, Bairro Santa Cecília, Porto Alegre, RS, CEP 90035-003, Brasil. Phone: +55 (51) 3308-5066. Fax: +55 (51) 3308-5470. E-mail: rosa_almeida@yahoo.com or rosa. almeida@ufrgs.br 
(Consiglio \& Bridges, 2009; Erskine, Barfield, \& Goldman, 1978).

Social instigation is a social experimental protocol used to increase aggressive behavior, in which excessive levels of aggressive behavior can be induced in laboratory animals. Attacks by mice, rats, and hamsters begin with a very low latency and high frequency when tested with an intruder in the resident's box or an unfamiliar place where the animal was previously provoked by an opponent (De Almeida \& Miczek, 2002; Fish, Faccidomo, \& Miczek, 1999; Potegal, 1991). Our research group recently showed that lactating rats exhibit a significant increase in the levels of aggression when subjected to social instigation (Veiga, Miczek, Lucion, \& De Almeida, 2011).

Analyses of the expression of immediate early genes such as c-fos have been used to understand the neural basis of maternal behavior (Gammie \& Nelson, 2001). In rats, aggressive confrontations activate Fos protein in the prefrontal cortex (PFC; Halász, Tóth, Kalló, Liposits, \& Haller, 2006; Haller, Tóth, Halász, \& De Boer, 2006). The ventro-orbital PFC (VO PFC) has been identified as an important area for the inhibitory control of subcortical circuits that mediate aggressive and impulsive behavior (Blair, 2001, 2004; Cardinal, Winstanley, Robbins, \& Everitt, 2004; Kheramin et al., 2005; Séguin, 2004; Veiga, Miczek, Lucion, \& De Almeida, 2007). Another region that has been implicated in the modulation of maternal aggression is the dorsal raphe nucleus (DRN). Our group recently showed that microinjection of the serotonin 5-hydroxytryptamine-1A (5- $\left.\mathrm{HT}_{1 \mathrm{~A}}\right)$ receptor agonist 8-OH-DPAT into the DRN increased aggressive behavior (Veiga et al., 2011).

The majority of studies on aggression have focused on physiological mechanisms (Davis \& Marler, 2004), but little is known about the neural mechanisms of maternal aggressive behavior (Consiglio, Borsoi, Pereira, \& Lucion, 2005; De Almeida, \& Lucion, 1997; Factor, Mayer, \& Rosenblatt, 1993; Ferreira, Dahlof, \& Hansen, 1987; Giovenardi, Padoin, Cadore, \& Lucion, 1998; Insel, 1986; Lonstein \& Gammie, 2002; Nelson \& Trainor, 2007; Russel \& Leng, 1998; Svare, 1990). The aim of the present study was to evaluate VO PFC and DRN activation reflected by Fos expression in lactating rats that were subjected to social instigation and aggressive behavior.

\section{Materials and Methods}

\section{Animals}

We used primiparous female Wistar rats $\sim 90$ days of age from the Universidade Federal do Rio Grande do Sul. Each rat was placed and kept individually in transparent acrylic boxes $(46 \mathrm{~cm} \times 31 \mathrm{~cm} \times 17 \mathrm{~cm})$ with free access to water and food. The date of birth of the pups was controlled and established as PPD 0. On PPD 1, the pups were standardized to eight per litter, regardless of the sex of the pups. The animals were kept under controlled temperature $\left(21 \pm 1^{\circ} \mathrm{C}\right)$ and a $12 \mathrm{~h} / 12 \mathrm{~h}$ light/dark cycle (lights off at 6:00 PM). To test aggressive behavior in lactating females, we used $\sim 150$ g male rat intruders. Instigators were also used, which were protected by an acrylic tube and did not have direct contact with the residents. Intruders and instigators were kept in groups of five animals per cage. The instigators were never previously used as intruders. The experiments were performed in accordance with the standards of the Brazilian College of Animal Experimentation (COBEA) and approved by the Ethics Committee of the institution.

\section{Resident intruder confrontation}

On PPD 3, females were selected for aggressive behavior as in Veiga et al. (2011). The behavioral test was conducted in the female resident's box in the presence of the pups at the beginning of the dark period.

\section{Social instigation}

Social instigation was performed on PPD 5 (Figure 1). Social instigation consisted of placing an acrylic tube with holes $(28 \mathrm{~cm}$ length, $10 \mathrm{~cm}$ diameter) that contained an opponent (stimulus) male or instigator (Figure 1A) for $5 \mathrm{~min}$ in the resident female's box (Veiga et al., 2011). Residents typically threaten the protected stimulus male and attack the perforated cylindrical tube. The pups remained in the box with their mothers during social instigation.

\section{Maternal aggressive behavior}

Five minutes after the social challenge on PPD 5, maternal aggressive behavior against a male intruder was assessed for $10 \mathrm{~min}$. The behavioral repertoire that we analyzed was described previously (De Almeida \& Lucion, 1997). Social instigation and aggressive behavior were videotaped and later analyzed by the experimenter using Observer software (version 3.0, Noldus, The Netherlands). We determined the frequency of aggressive behaviors including lateral attacks, bites on the body, and an intrusive and aggressive stance.

Lactating rats were divided into the following groups: (1) no social instigation and no aggressive behavior (NI + NA; the acrylic tube was placed empty, without the stimulus rat, into the resident's box, and the rats were not subjected to maternal aggressive behavior), (2) social instigation and no aggressive behavior (I + NA; the acrylic tube was placed into the resident's box with the stimulus rat, and the rats were not subjected to maternal aggressive behavior), (3) no social instigation and aggressive behavior (NI $+\mathrm{A}$; the acrylic tube was placed empty, without the stimulus rat, into the resident's box, and the rats were subjected to maternal aggressive behavior), and (4) social instigation and aggressive behavior $(\mathrm{I}+\mathrm{A}$; the acrylic tube was placed into the resident's box with the stimulus rat, and the rats were subjected to maternal aggressive behavior). 

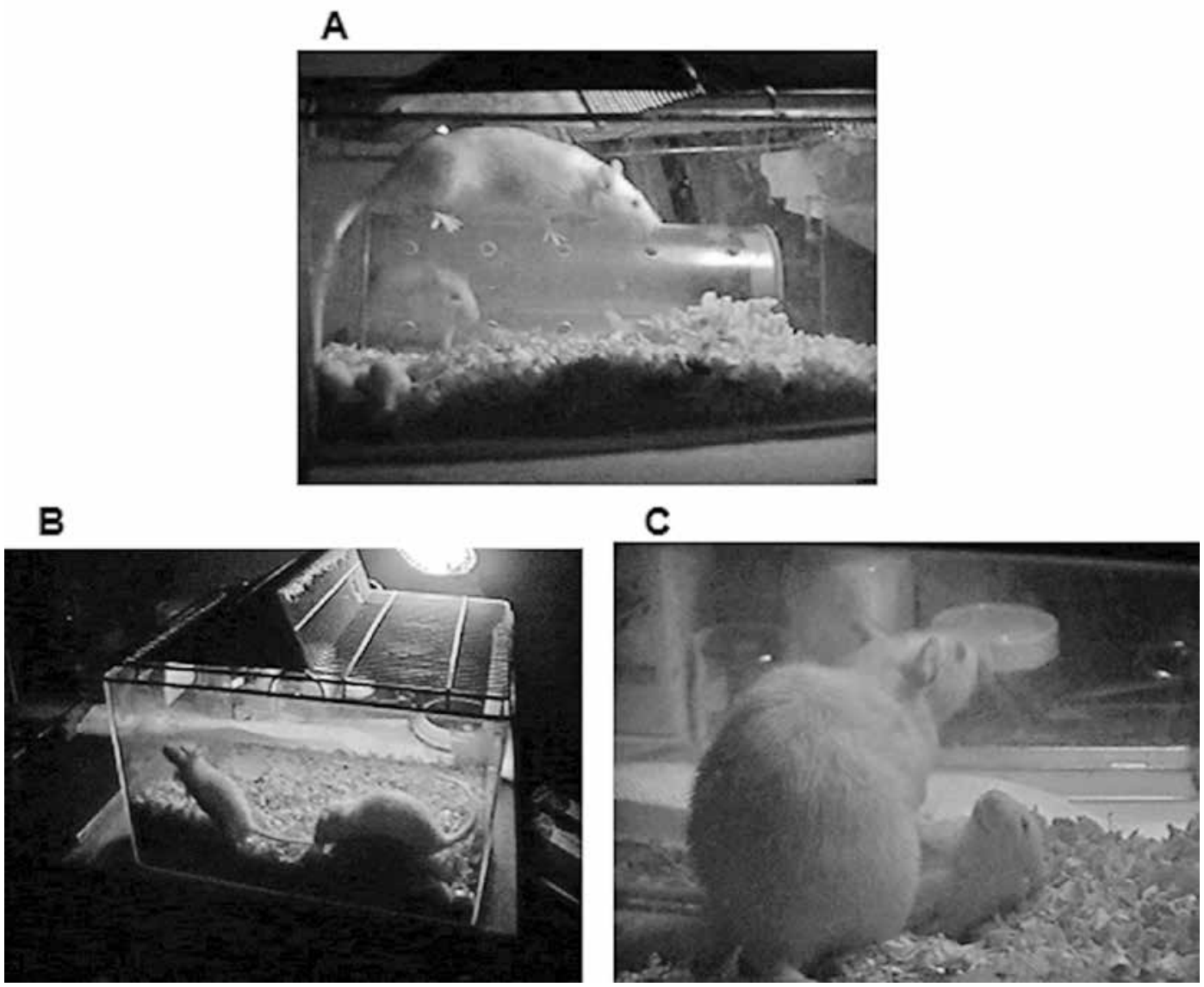

Figure 1. (A) Resident lactating rat and instigator rat in the acrylic tube during social instigation in the resident's box on postpartum day 5 in the presence of pups. (B) Investigative behavior of the female rat during resident intruder confrontation in the box for 10 min. (C) Resident dominating the intruder.

\section{Immunohistochemical detection of Fos protein immunoreactivity}

On PPD 5, 80 min after the beginning of social instigation, the four experimental groups of rats were analyzed for Fos protein expression in the DRN and VO PFC. The control group was not subjected to social instigation or aggressive behavior before the beginning of this experimental phase, with only an empty tube placed inside the resident's cage. Simultaneously, the rats were deeply anesthetized with sodium pentobarbital $(50 \mathrm{mg} / \mathrm{kg}$, i.p.), and transcardiac perfusion was performed by injecting $150 \mathrm{ml}$ saline followed by $4 \%$ paraformaldehyde diluted in $150 \mathrm{mg}$ of $0.1 \mathrm{M}$ sodium phosphate buffer, $\mathrm{pH}$ 7.4. The brains were then removed and kept in a $4 \%$ paraformaldehyde fixative solution for $8 \mathrm{~h}$ at room temperature. Subsequently, the brains were cryoprotected in a $30 \%$ sucrose solution at $4^{\circ} \mathrm{C}$. The brains were then cut into $50-\mu \mathrm{m}$-thick coronal sections using a cryostat and collected free-floating. The slices were kept immersed in an antifreeze solution (phosphate-buffered saline [PBS] that contained distilled water, sucrose, and propylene glycol; Vetec, São Paulo, Brazil) and stored at $-70^{\circ} \mathrm{C}$ until the day of immunohistochemical Fos detection. All of the brains were processed together to detect Fos protein using avidin-biotin-peroxidase as in Cezario, Ribeiro-Barbosa, Baldo, \& Canteras (2008).
The brain sections were washed three times for $10 \mathrm{~min}$ each in PBS and incubated in buffer solution with Triton X-100 (Sigma, St. Louis, MO, USA), normal goat serum, and rabbit anti-Fos antibody (Ab-5; Calbiochem, San Diego, CA, USA) at a 1:20,000 dilution for $48 \mathrm{~h}$ at $4^{\circ} \mathrm{C}$ with continuous stirring. After this period, the sections were incubated for $90 \mathrm{~min}$ at room temperature in a 1:250 solution of biotinylated goat immunoglobulin $\mathrm{G}$ anti-rabbit (Vector Laboratories, Burlingame, CA, USA), mixed, and then incubated for $90 \mathrm{~min}$ in a solution that contained avidin-biotin peroxidase at a dilution of 1:250 (ABC Elite Kit; Vector Laboratories). The visualization of the peroxidase complex occurred after exposure for $10 \mathrm{~min}$ in a chromogen solution that contained 0.02\% 3,3-diaminobenzidine (DAB; Sigma, St. Louis, MO, USA) with $0.3 \%$ nickel sulfate in 0.05 $\mathrm{M}$ Tris buffer ( $\mathrm{pH} 7.6$ ), followed by 5 min incubation in a $0.01 \%$ solution of glucose oxidase (glucose oxidase Type VII from Aspergillus niger; Sigma) and 10\% Pd-glucose (Sigma) to produce a dark blue color. For negative control of enzyme activity some sections were randomly processed by omitting the primary antibody. All sections were then washed with buffer, collected on previously gelatinized slides, dehydrated in ethanol, cleared with xylene, and mounted with coverslips using distyrene/plasticizer/xylene. 


\section{Quantification of Fos-positive cells}

The VO PFC and DRN regions were identified according to the Paxinos \& Watson (1998) rat brain atlas. To quantify cells that were immunohistochemically stained for Fos protein, we used a Zeiss Axioscop2 microscope with a $20 \times$ objective and a charge-coupled device video camera coupled to an Apple Macintosh 8600-300 computer and NIH Image 1.62f analysis system. Neuronal quantification was performed using both hemispheres (Davis \& Marler, 2004; Madruga, Xavier, Achaval, Sanvitto, \& Lucion, 2006), and neurons were counted inside a $13,887 \mu \mathrm{m}^{2}$ frame (i.e., test area) according to previous studies of Fos expression in rodents (Davis \& Marler, 2004; Gammie \& Nelson, 2001). Neurons outside the outer forbidden lines were not counted (Camozzato et al., 2009; Wilkelmann-Duarte et al., 2007). Slices were made from each region along its entire length with a $200-\mu \mathrm{m}$ gap. In the VO PFC, slices were made $3.70-5.20 \mathrm{~mm}$ anterior to bregma. In the DRN, slices were made 7.04-8.0 mm posterior to bregma (Paxinos \& Watson, 1998). For the DRN, the cell counts reflected the sum of the proximal and distal parts with the aqueduct as a reference. Data are expressed as the average number of neurons in each region within the test area. All quantifications of labeled cells were performed by two experimenters unrelated to the study.

\section{Statistical analysis}

The results are expressed as mean \pm SEM. Fos immunoreactivity results in the VO PFC and DRN in the four experimental groups (NI + NA, I + NA, NI + $\mathrm{A}$, and $\mathrm{I}+\mathrm{A}$ ) were analyzed using one-way analysis of variance (ANOVA) followed by the Newman-Keuls post $h o c$ test. Values of $p<.05$ were considered statistically significant. Aggressive behavior in females in the two groups tested for aggressiveness $(\mathrm{NI}+\mathrm{A}$ and $\mathrm{I}+\mathrm{A}$ ) were analyzed using Student's $t$-test.

\section{Results}

Microscopic analysis of Fos protein expression in the VO PFC showed that lactating rats subjected to social instigation and aggressive behavior exhibited a statistically significant increase in the number Fospositive cells $\left(F_{3,17}=3.30, p<.05\right.$; Figures 2 and 3$)$ compared with the control group (i.e., no social instigation and no aggressive behavior). No significant difference was found between groups in Fos expression in the DRN $\left(F_{3,16}=.64, p=.5\right.$; Figures 4 and 5$)$.

Socially instigated lactating rats subjected to aggressive confrontation exhibited a significant increase in the frequency of lateral attacks $\left(t_{9}=2.43, p<.04\right.$; Figure 6) compared with the control group (i.e., no social instigation and no aggressive behavior).

\section{Discussion}

The present study showed that lactating rats subjected to social instigation and aggressive behavior

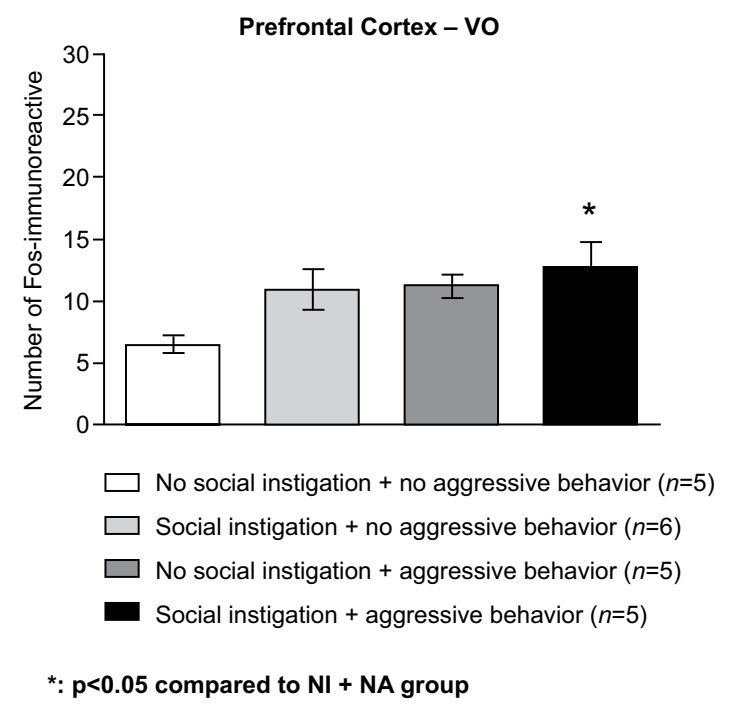

Figure 2. Mean $( \pm \mathrm{SEM})$ number of Fos-immunoreactive cells in the ventral-orbital (VO) prefrontal cortex in rats subjected to social instigation and aggressive behavior on postpartum day 5 in the presence of pups. ${ }^{*} p<.05$, compared with control group (no social instigation and no aggressive behavior).
A

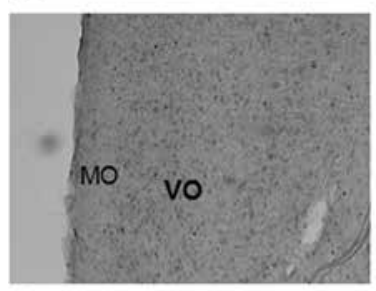

C

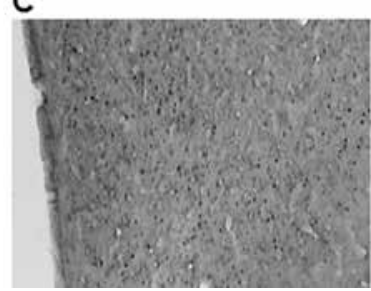

B

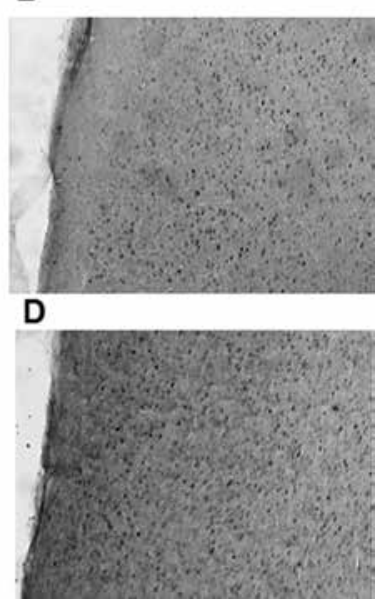

Figure 3. Coronal sections of the rat brain that show the region of Fos-immunoreactive cells in the VO PFC in the (A) control group, (B) social instigation and no aggressive behavior group, (C) no social instigation and aggressive behavior group, and (D) social instigation and aggressive behavior group. A significant increase in the number of Fos-positive cells was found in the VO PFC, concomitant with the expression of maternal aggressive behavior (D).

against a male intruder in the presence of their pups on PPD 5 exhibited an increase in Fos protein expression specifically in the VO PFC. No change was observed in Fos expression in the DRN in lactating rats after exposure to social instigation or aggressive behavior. Analyses of the increased expression of transcription factors such as c-fos in association with specific behaviors (e.g., maternal aggression) have provided important indirect evidence of neural activity in a subregion of cells during the execution of a certain behavior (Gammie \& Nelson, 2001).

No studies of which we are aware have demonstrated the brain regions that have increased Fos expression in lactating rats subjected to experimental protocols 


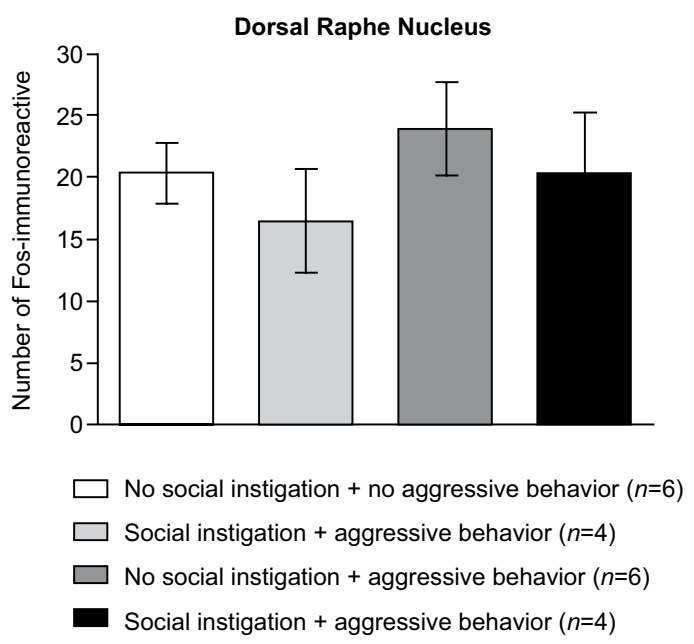

Figure 4. Mean $( \pm$ SEM) number of Fos-immunoreactive cells in the dorsal raphe nucleus (DRN), proximal and distal to the aqueduct, in resident lactating rats subjected to social instigation and aggressive behavior on postpartum day 5 in the presence of pups.

A

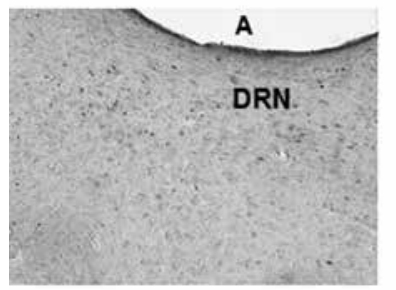

C

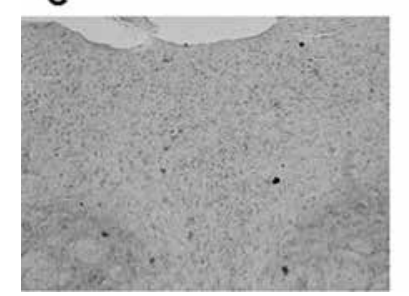

Figure 5. Coronal sections of the rat brain showing the DRN (proximal, relative to the aqueduct $[\mathrm{Aq}]$ ) where Fos-immunoreactive cells were quantified in the (A) control group (no social instigation and no aggressive behavior), (B) social instigation and aggressive behavior group, (C) no social instigation and aggressive behavior group, and (D) social instigation and aggressive behavior group.

\section{Lateral attack}

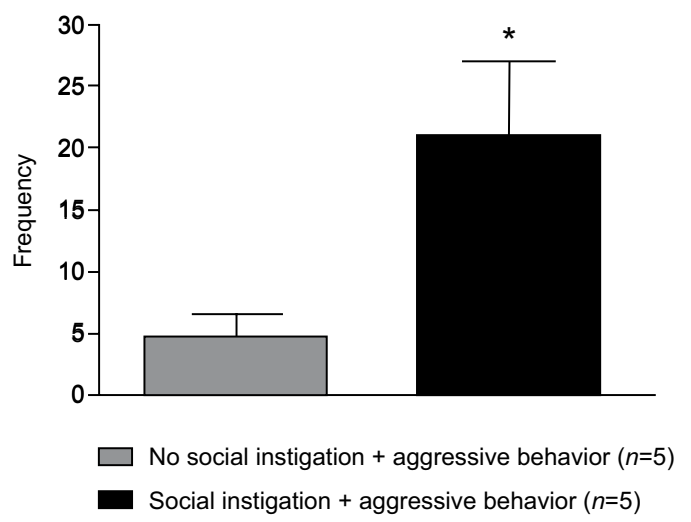

Figure 6. Effect of social instigation on aggressive behavior (i.e., lateral attacks) in lactating rats on postpartum day 5 in the presence of pups. of aggression such as social instigation. Some studies have shown an increase in Fos expression in the medial amygdala, bed nucleus of the stria terminalis, paraventricular nucleus of the hypothalamus, and periaqueductal gray after maternal aggression (Gammie $\&$ Nelson, 2001). Parental male mice that take care of offspring exhibit an increase in Fos expression in the medial preoptic area, ventromedial hypothalamus, and medial amygdala (Trainor, Finy, \& Nelson, 2008), and these same regions also express Fos in the context of maternal aggression (Gammie, 2005). Fos is expressed for only short periods of time (15-90 $\mathrm{min}$ ) after exposure to a stimulus (Morgan, Cohen, Hempstead, \& Curran, 1987; Morgan \& Curran, 1991; Gammie \& Nelson, 2001; Knyshevski, Connor, Harrison, Ricci, \& Melloni, 2005). However, some studies have shown that Fos expression can persist, representing cellular activation in response to chronic physiological (Fenelon, Poulain, \& Theodosis, 1993; Miyata, Nakashima, \& Kiyohara, 1994) and behavioral (Fenelon et al., 1993; Matsuda, Peng, Yoshimura, Wen, Fukuda, \& Sakanaka, 1996) stimuli.

Experiments conducted with male rats found that, compared to $\mathrm{LO}$ and $\mathrm{VO}$, regions of the prefrontal cortex cause an increase in neuronal activation after aggressive encounters (Halasz et al., 2006), and this activation was particularly higher in male mice previously selected for high rates of aggression (Haller et al., 2006). Thus, the increased expression of Fos in the VO PFC in the present study is similar to previous studies.

The manifestations of abnormal aggressive behavior are related to or caused by decreased prefrontal cortex activity (Damasio, Grabowski, Frank, Galaburda, \& Damasio, 1994; Volkow et al., 1995; Golden, Jackson, Peterson-Rhone, \& Gontkovsky, 1996; Critchley et al., 2000; Davidson, Putnam, \& Larson, 2000; Hawkins \& Trobst, 2000; Bassarath, 2001; Best, Williams, \& Coccaro, 2002; Veit et al., 2002; Blair, 2004; Halász et al., 2006). In contrast to these results, however, the present study found that social instigation followed by aggressive behavior increased neuronal activation in the VO PFC, and other studies have also shown similar results (Halász et al., 2006; Haller et al., 2006). Halász et al. (2006) argued that this discrepancy with regard to PFC deficiency in humans who exhibit violent behaviors are not found in rodents and can be explained by the differences between the acute and chronic functioning of the PFC. For example, acute activation as observed in the present study and chronic dysfunction in violent persons may affect aggressive behavior through independent mechanisms. Prefrontal cortex deficiencies have been shown to alter moral judgments in humans, and behavioral disturbances have been suggested to occur through this route (Price, Daffner, Stowe, \& Mesulam, 1990; Nichelli, Grafman, Pietrini, Clark, Lee, \& Miletich, 1995; Greene, Nystrom, Engell, Darley, \& Cohen, 2004; Luo, Nakic, Wheatley, Richell, Martin, \& Blair, 2006). Thus, prefrontal deficits lead to violence via deficiencies in moral judgments (Halász et al., 2006). In contrast, acute activation of the PFC 
may contribute to the expression of aggressive behavior, which is supported by the present results and previous studies in rodents (Halász et al., 2006).

The observation of Fos-positive serotonergic neurons in the DRN is consistent with previous work from our group. Microinjection of the $5-\mathrm{HT}_{1 \mathrm{~A}}$ receptor agonist 8-OH-DPAT into the DRN increased aggressive behavior in lactating rats (Veiga et al., 2011), which possibly exhibit a reduction of serotonin in this area. A more detailed analysis using Fos immunohistochemistry with co-labeling for serotonergic neurons may provide more support for the results obtained in this work.

In summary, the present results demonstrated that lactating rats subjected to social instigation and aggressive behavior on PPD 5 exhibited an increase in Fos expression in the VO PFC in the presence of their pups, but no changes in Fos expression were found in the DRN. Future experiments that analyze Fos immunohistochemistry in other brain regions in lactating rats subjected to social instigation and aggressive behavior may further elucidate the modulation and expression of maternal aggression.

\section{References}

Agrati, D., Zuluaga, M. J., Fernández-Guasti, A., Meikle, A., \& Ferreira, A. (2008). Maternal condition reduces fear behaviors but not the endocrine response to an emotional threat in virgin female rats. Hormones and Behavior, 53(1), 232-240.

Bassarath, L. (2001). Neuroimaging studies of antisocial behavior. Canadian Journal of Psychiatry, 46, 728-732.

Best, M., Williams, J. M., \& Coccaro, E. F. (2002). Evidence for a dysfunctional prefrontal circuit in patients with an impulsive aggressive disorder. Proceedings of the National Academy of Sciences of the United States of America, 99, 8448-8453.

Blair, R. J. (2001). Neurocognitive models of aggression, the antisocial personality disorders, and psychopathy. Journal of Neurology, Neurosurgery and Psychiatry, 71, 727-731.

Blair, J. R. (2004). The roles of orbital frontal cortex in the modulation of antisocial behavior. Brain and Cognition, 55, 198-208.

Bridges, R. (1996). Biochemical basis of paternal behavior in the rat. In J. S. Rosenblatt, \& C. T. Snowdon (Eds.), Parental care: evolution, mechanisms, and adaptive significance (pp. 215-242). San Diego: Academic Press.

Camozzato, T. S., Winkelmann-Duarte, E. C., Padilha, C. B., Miguel, S. P., Bonzanini, L., Anselmo-Franci, J. A., Fernandes, M. C., \& Lucion, A. B. (2009). Neonatal handling reduces the number of cells in the medial preoptic area of female rats. Brain Research, 247, 92-99.

Cardinal, R. M., Winstanley, C. A., Robbins, T. W., \& Everitt, B. J. (2004). Limbic corticostriatal systems and delayed reinforcement. Annals of the New York Academy of Sciences, 1021, 33-50.

Cezario, A. F., Ribeiro-Barbosa, E. R., Baldo, M. V., \& Canteras, N. S. (2008). Hypothalamic sites responding to predator threats: The role of the dorsal premammillary nucleus in unconditioned and conditioned antipredatory defensive behavior. European Journal of Neuroscience, 28, 1003-1015.

Consiglio, A. R., Borsoi, A., Pereira, G., \& Lucion, A. B. (2005). Effects of oxytocin microinjected into the central amygdaloid nucleus and bed nucleus of the stria terminalis on maternal aggressive behavior in rats. Physiology and Behavior, 85, 354-362.

Consiglio, A. R., \& Bridges, R. S. (2009). Circulating prolactin, MPOA prolactin receptor expression and maternal aggression in lactating rats. Behavioural Brain Research, 197, 97-102.

Critchley, H. D., Simmons, A., Daly, E. M., Russell, A., van Amelsvoort, T., Robertson, D. M., Glover, A., \& Murphy, D. G. (2000). Prefrontal and medial temporal correlates of repetitive violence to self and others. Biological Psychiatry, 47, 928-934.

Damasio, H., Grabowski, T., Frank, R., Galaburda, A. M., \& Damasio, A. R. (1994). The return of Phineas Gage: Clues about the brain from the skull of a famous patient. Science, 264, 1102-1105.
Davidson, R. J., Putnam, K. M., \& Larson, C. L. (2000). Dysfunction in the neural circuitry of emotion regulation: A possible prelude to violence. Science, 289, 591-594.

Davis, E. S., \& Marler, C. A. (2004). C-FOS changes following an aggressive encounter in female California mice: A synthesis of behavior, hormone changes and neural activity. Neuroscience, 127, 611-624.

De Almeida, R. M. M., \& Lucion, A. B. (1997). 8-OH-DPAT in the median raphé, dorsal periaqueductal gray and corticomedial amygdala nucleus decreases, but the medial septal area it can increase maternal aggressive behavior in rats. Psychopharmacology, $134,392-400$

De Almeida, R. M. M., \& Miczek, K. A. (2002). Aggression escalated by social instigation or by discontinuation of reinforcement ("frustration") in mice: Inhibition by anpirtoline: a 5-HT ${ }_{1 \mathrm{~B}}$ receptor agonist. Neuropsychopharmacology, 272, 171-181.

Erskine, M. S., Barfield, R. J., \& Goldman, B. D. (1978). Intraspecific fighting during late pregnancy and lactation in rats and effects of litter removal. Behavioral Biology, 23, 206-218.

Erskine, M. S., Barfield, R. J., \& Goldman, B. D. (1980). Postpartum aggression in rats: I. Effects of hypophysectomy. Journal of Comparative and Physiological Psychology, 94, 484-494.

Factor, E. M., Mayer, A. D., \& Rosenblatt, J. S. (1993). Peripeduncular nucleus lesions in the rat: I. Effects on maternal aggression, lactation, and maternal behavior during pre- and postpartum periods. Behavioral Neuroscience, 107, 166-185.

Fenelon, V. S., Poulain, D. A., \& Theodosis, D. T. (1993). Oxytocin neuron activation and Fos expression: A quantitative immunocytochemical analysis of the effect of lactation, parturition, osmotic and cardiovascular stimulation. Neuroscience, 53, 77-89.

Ferreira, A., Dahlof, L. G., \& Hansen, S. (1987). Olfactory mechanisms in the control of maternal aggression, appetite, and fearfulness: Effects of lesions to olfactory receptors, mediodorsal thalamic nucleus, and insular prefrontal cortex. Behavioral Neuroscience, 101, 709-717; see also p. 746

Ferreira, A., Pereira, M., Agrati, D., Uriarte, N., \& Fernández-Guasti, A. (2002). Role of maternal behavior on aggression, fear and anxiety. Physiology and Behavior, 77, 197-204.

Fish, E. W., Faccidomo, S., \& Miczek, K. A. (1999). Aggression heightened by alcohol or social instigation in mice: reduction by the 5-HT ${ }_{1 \mathrm{~B}}$ receptor agonist CP-94,253. Psychopharmacology, 146, 391-399.

Gammie, S. C., \& Nelson, R. J. (2001). cFOS and pCREB activation and maternal aggression in mice. Brain Research, 898, 232-241.

Gammie, S. C. (2005). Current models and future directions for understanding the neural circuitries of maternal behaviors in rodents. Behavioral and Cognitive Neuroscience Reviews, 4, 119-135.

Giovenardi, M., Padoin, M. J, Cadore, L .P., \& Lucion, A. B. (1998). Hypothalamic paraventricular nucleus modulates maternal aggression in rats: Effects of ibotenic acid lesion and oxytocin antisense. Physiology and Behavior, 63, 351-359.

Giovenardi, M., Consiglio, A. R., Barros, H. T. M., \& Lucion, A. B. (2000). Pup age and aggressive behavior in lactating rats. Brazilian Journal of Medical and Biological Research, 33, 1083-1088.

Golden, C. J., Jackson, M. L., Peterson-Rohne, A., \& Gontkovsky, S. T. (1996). Neuropsychological correlates of violence and aggression: A review of the clinical literature. Aggression and Violent Behavior, 1, 3-25.

Greene, J. D., Nystrom, L. E., Engell, A. D., Darley, J .M., \& Cohen, $J$.D. (2004). The neural bases of cognitive conflict and control in moral judgment. Neuron, 44, 389-400.

Halász, J., Tóth, M., Kalló, I., Liposits, Z., \& Haller, J. (2006). The activation of prefrontal cortical neurons in aggression: A double labeling study. Behavioural Brain Research, 175, 166-175.

Haller, J., Tóth, M., Halász, J., \& De Boer, S. F. (2006). Patterns of violent aggression-induced brain c-fos expression in male mice selected for aggressiveness. Physiology and Behavior, 88, 173182.

Hawkins, K. A., \& Trobst, K. K. (2000). Frontal lobe dysfunction and aggression: Conceptual issues and research findings. Aggression and Violent Behavior, 5, 147-157.

Insel, T. R. (1986). Postpartum increases in brain oxytocin binding. Neuroendocrinology, 44, 515-518.

Kheramin, S., Body, S., Herrera, F. M., Bradshaw, C. M., Szabadi, E., Deakin, J. F., \& Anderson, I. M. (2005). The effect of orbital prefrontal cortex lesions on performance on a progressive ratio schedule: implications for models of inter-temporal choice. Behavioural Brain Research, 156, 145-152. 
Kinsley, C. H., \& Bridges, R. S. (1990). Morphine treatment and reproductive condition alter olfactory preferences for pup and adult male odors in female rats. Developmental Psychobiology, 23, 331347.

Knyshevski, I., Connor, D. F., Harrison, R. J., Ricci, L. A., \& Melloni, R. H., Jr. (2005). Persistent activation of select forebrain regions in aggressive, adolescent cocaine-treated hamsters. Behavioural Brain Research, 159, 277-286.

Lonstein, J. S., \& Gammie, S. C. (2002). Sensory, hormonal, and neural control of maternal aggression in laboratory rodents. Neuroscience and Biobehavioral Reviews, 26, 869-888.

Luo, Q., Nakic, M., Wheatley, T., Richell, R., Martin, A., \& Blair, R. J. (2006). The neural basis of implicit moral attitude: An IAT study using event-related fMRI. Neuroimage, 30, 1449-1457.

Madruga, C. S., Xavier, L. L., Achaval, M., Sanvitto, G. L., \& Lucion, A. B. (2006). Early handling, but not maternal separation, decreases emotional responses in two paradigms of fear without changes in mesolimbic dopamine. Behavioural Brain Research, 166, 241-246.

Matsuda, S., Peng, H., Yoshimura, H., Wen, T. C., Fukuda, T., \& Sakanaka, M. (1996). Persistent c-fos expression in the brains of mice with chronic social stress. Neuroscience Research, 26, 157-170.

Miyata, S., Nakashima, T., \& Kiyohara, T. (1994). Expression of c-fos immunoreactivity in the hypothalamic magnocellular neurons during chronic osmotic stimulations. Neuroscience Letters, 175 , 63-66.

Morgan, J. I., Cohen, D. R., Hempstead, J. L., \& Curran, T. (1987). Mapping patterns of c-fos expression in the central nervous system after seizure. Science, 237, 192-197.

Morgan, J. I., \& Curran, T. (1991). Stimulus-transcription coupling in the nervous system: Involvement of the inducible proto-oncogenes fos and jun. Annual Review of Neuroscience, 14, 421-451.

Nelson, R. J., \& Trainor, B. C. (2007). Neural mechanisms of aggression. Nature Reviews Neuroscience, 8(7), 536-546.

Nichelli, P., Grafman, J., Pietrini, P., Clark, K., Lee, K. Y., \& Miletich, R. (1995). Where the brain appreciates the moral of a story. Neuroreport, 6, 2309-2313.

Olivier, B., \& Young, L. J. (2002). Animal models of aggression. In K. L. Davis, D. Charney, J. T. Coyle, \& C. Nemeroff (Eds.), Neuropsychopharmacology: The fifth generation of progress (pp. 1699-1708). Philadelphia: Lippincott Williams and Wilkins.

Paxinos, G., \& Watson, C. (1998). The rat brain in stereotaxic coordinates, 4 th edition. San Diego: Academic Press.
Potegal, M. (1991). Attack priming and satiation in female golden hamsters: Tests of some alternatives to the aggression arousal interpretation. Aggressive Behavior, 17, 327-335.

Price, B. H., Daffner, K. R., Stowe, R. M., \& Mesulam, M. M. (1990). The compartmental learning disabilities of early frontal lobe damage. Brain, 113, 1383-1393.

Rosenblatt, J. S. (1975). Selective retrieving by maternal and nonmaternal female rats. Journal of Comparative and Physiological Psychology, 88, 678-686.

Russel, J. A., \& Leng, G. (1998). Sex, parturition and motherhood without oxytocin? Journal of Endocrinology, 157, 343-359.

Séguin, J. R. (2004). Neurocognitive elements of antisocial behavior: Relevance of an orbitofrontal cortex account. Brain and Cognition, $55,185-197$

Svare, B. (1990). Maternal aggression: hormonal, genetic, and developmental determinants. In N. A. Krasnegor, \& R. S. Bridges (Eds.), Mammalian parenting: Biochemical, neurobiological, and behavioral determinants (pp. 118-132). New York: Oxford University Press.

Trainor, B. C., Finy, M. S., \& Nelson, R. J. (2008). Paternal aggression in a biparental mouse: Parallels with maternal aggression. Hormones and Behavior, 53, 200-207.

Veiga, C. P., Miczek, K. A., Lucion, A. B., \& De Almeida, R. M. M. (2007). Effect of 5-HT1B receptor agonists injected into the prefrontal cortex on maternal aggression in rats. Brazilian Journal of Medical and Biological Research, 40, 825-830.

Veiga, C. P., Miczek, K. A., Lucion, A. B., \& De Almeida, R. M. M. (2011). Social instigation and aggression in postpartum female rats: Role of 5-HT $\mathrm{HA}_{1 \mathrm{~A}}$ and $5-\mathrm{HT}_{1 \mathrm{~B}}$ receptors in the dorsal raphé nucleus and prefrontal cortex. Psychopharmacology, 213, 475-487.

Veit, R., Flor, H., Erb, M., Hermann, C., Lotze, M., Grodd, W., \& Birbaumer, N. (2002). Brain circuits involved in emotional learning in antisocial behavior and social phobia in humans. Neuroscience Letters, 328, 233-236.

Volkow, N. D., Tancredi, L. R., Grant, C., Gillespie, H., Valentine, A., Mullani, N., Wang, G. J., \& Hollister, L. (1995). Brain glucose metabolism in violent psychiatric patients: A preliminary study. Psychiatry Research, 61, 243-253.

Winkelmann-Duarte, E. C., Todeschin, A. S., Fernandes, M. C., Bittencourt, L. C., Pereira, G. A. M., Samios, V. N., ... Lucion, A. B. (2007). Plastic changes induced by neonatal handling in the hypothalamus of female rats. Brain Research, 1170, 20-30. 
